\title{
STRATEGI MENINGKATKAN LOYALITAS PELANGGAN PADA PT GOLDEN BATAM RAYA
}

\author{
Hendri Herman \\ Universitas Putera Batam \\ email: hendrihermanbatam@gmail.com
}

\begin{abstract}
The purpose of this study is to look at customer loyalty in terms of price. The study was conducted at PT Golden Batam Raya with total sample of 92 respondents. The results of this study that price has a significant effect on customer loyalty. The percentage of price effect on customer loyalty is $45,1 \%$. This value is large enough so that it is important fot the object of research to pay attention to the policies taken in setting the selling price of the product
\end{abstract}

Keywords: Price; Loyalty

\section{PENDAHULUAN}

Dalam dunia bisnis, pelanggan merupakan asset perusahaan yang harus dijaga agar pelanggan tetap setia terhadap produk yang dihasilkan dan ditawarkan oleh perusahaan. Tidak dapat dipungkiri jika banyak terdapat perusahaan-perusahaan lain yang sejenis yang menghasilkan produk yang sama yang tentunya akan menjadi pesaing perusahaan. Konsumen juga sebagai pembeli tentu menginginkan memperoleh produk dengan harga yang relative murah. Maka dari itu, penting bagi suatu perusahaan untuk dapat dengan baik dan tepat dalam menentukan harga jual produk. Tentu harga akan menentukan kualitas. Akan tetapi, dikarenakan terdapat banyak perusahaan sejenis yang menjadi pesaing, maka suatu perusahaan tidak dapat dengan ceroboh dalam menentukan harga jual. Kecerobohan dalam penentuan harga jual akan membuat produk kurang peminat dari pembeli.

Penelitian dilakukan di PT Golden Batam Raya, merupakan perusahaan yang menjual alat-alat listrik, perlengkapan listrik dan lampu-lampu kapal yang lengkap. Untuk dapat menguasai pasar dan mendapatkan loyalitas konsumen, maka perusahaan harus tepat dalam menentukan harga jual produknya. Dikarenakan terdapat beberapa perusahaan pesaing yang memiliki jenis usaha yang sama dengan PT Golden Batam Raya.

\section{TINJAUAN PUSTAKA}

\section{Harga}

Harga merupakan nilai nominal uang yang harus diserahkan atau dibayar oleh pembeli kepada perusahaan atau kepada penjual untuk mendapatkan barang tersebut. Harga merupakan salah satu faktor yang dipertimbangkan oleh konsumen dalam melakukan pembelian suatu produk, harga yang relative murah dan bersaing akan menarik minat para calon konsumen.

Menurut Kotler dan Keller (2009) harga merupakan suatu elemen dari bauran pemasaran (marketing mix) yang tidak saja menentukan tingkat keuntungan tetapi juga sebagai sinyal untuk mengkomunikasikan proporsi nilai suatu produk.

Indikator yang digunakan untuk variabel harga adalah sebagai berikut:

1. Keterjangkauan harga

2. Diskon/ potongan harga

3. Cara pembayaran

4. Negosiasi

5. Garansi 


\section{Loyalitas Pelanggan}

Loyalitas pelanggan merupakan suatu tindakan pelanggan untuk tetap setiap dalam membeli dan menggunakan produk atau jasa yang dihasilkan oleh suatu perusahaan. Banyak hal yang dapat membuat pelanggan setia terhadap pembelian suatu produk atau jasa. Salah satunya adalah harga yang bersaing.

Loyalitas merupakan kondisi psikologis yang berkaitan dengan sikap pelanggan terhadap suatu produk, konsumen akan membentuk keyakinan, menetapkan suka atau tidak suka, dan memutuskan apakah mereka ingin membeli produk tersebut atau tidak (Hasan, 2014)

Indikator loyalitas pelanggan diukur dengan (Tjiptono, 2005 dalam Sanadji, 2013):

1. Pembelian ulang

2. Kebiasaan mengonsumsi merek

3. Rasa suka yang besar pada merek

4. Ketetapan pada merek

5. Keyakinan bahwa merek tertentu merek yang terbaik

6. Perekomendasian merek kepada orang lain

\section{Hipotesis}

Adapun hipotesis dalam penelitian ini adalah harga memiliki pengaruh signifikan terhadap loyalitas pelanggan

\section{METODE}

Penelitian ini merupakan penelitian deskriptif kuantitatif dengan objek penelitian adalah PT Golden Batam Raya. Responden dalam penelitian ini adalah konsumen PT Golden Batam Raya yang telah melakukan pembelian ulang lebih dari satu kali. Jumlah sampel dalam penelitian ini adalah sebanyak 92 sampel

\section{HASIL DAN PEMBAHASAN}

\section{Uji Validitas Data}

Hasil uji validitas dalam penelitian ini dapat dilihat pada tabel berikut:

Tabel 1. Hasil Uji Validitas Harga

\begin{tabular}{|l|l|l|l|l|}
\hline No & Item & R hitung & R tabel & Kesimpulan \\
\hline 1 & X.1.1 & 0.632 & 0.2050 & Valid \\
\hline 2 & X.1.2 & 0.635 & 0.2050 & Valid \\
\hline 3 & X.1.3 & 0.723 & 0.2050 & Valid \\
\hline 4 & X.1.4 & 0.833 & 0.2050 & Valid \\
\hline 5 & X.1.5 & 0.917 & 0.2050 & Valid \\
\hline
\end{tabular}

Berdasarkan tabel di atas, dapat dilihat bahwa nilai $\mathrm{r}$ hitung masing-masing variabel harga lebih besar dari nilai $r$ tabel (0.2050). sehingga dapat disimpulkan bahwa semua item dalam variabel harga adalah valid.

Tabel 2. Hasil Uji Validitas Loyalitas

\begin{tabular}{|l|l|l|l|l|}
\hline No & Item & R hitung & R tabel & Kesimpulan \\
\hline 1 & Y.1 & 0.516 & 0.2050 & Valid \\
\hline 2 & Y.2 & 0.606 & 0.2050 & Valid \\
\hline 3 & Y.3 & 0.621 & 0.2050 & Valid \\
\hline 1 & Y.1 & 0.716 & 0.2050 & Valid \\
\hline 2 & Y.2 & 0.506 & 0.2050 & Valid \\
\hline 3 & Y.3 & 0.421 & 0.2050 & Valid \\
\hline
\end{tabular}

Berdasarkan tabel di atas, dapat dilihat bahwa nilai $r$ hitung masing-masing variabel loyalitas lebih besar dari nilai $r$ tabel (0.2050). sehingga dapat disimpulkan bahwa semua item dalam variabel loyalitas adalah valid. 


\section{Uji Reliabilitas}

Tabel 3. Hasil Uji Reliabilitas

Hasil uji reliabilitas dalam penelitian ini dapat dilihat pada tabel berikut:

\begin{tabular}{|l|l|l|l|}
\hline No & Variabel & Cronbach Alpha & Kesimpulan \\
\hline 1 & Harga & 0.673 & Reliabel \\
\hline 2 & Loyalitas Pelanggan & 0.854 & Reliabel \\
\hline
\end{tabular}

Berdasarkan tabel di atas, dapat dilihat bahwa masing-masing nilai cronbach alpha pada variabel harga dan loyalitas pelanggan sebesar 0.673 dan 0.854 . nilai cronbach alpha ini lebih besar dari 0.6. sehingga disimpulkan bahwa item-item dalam variabel ini adalah reliabel.

\section{Uji Asumsi Klasik}

Uji Normalitas

Uji normalitas dalam penelitian, dapat dilihat pada tabel Kolmogorov berikut ini:

Tabel 4. Hasil Uji Normalitas.

One-Sample Kolmogorov-Smirnov Test

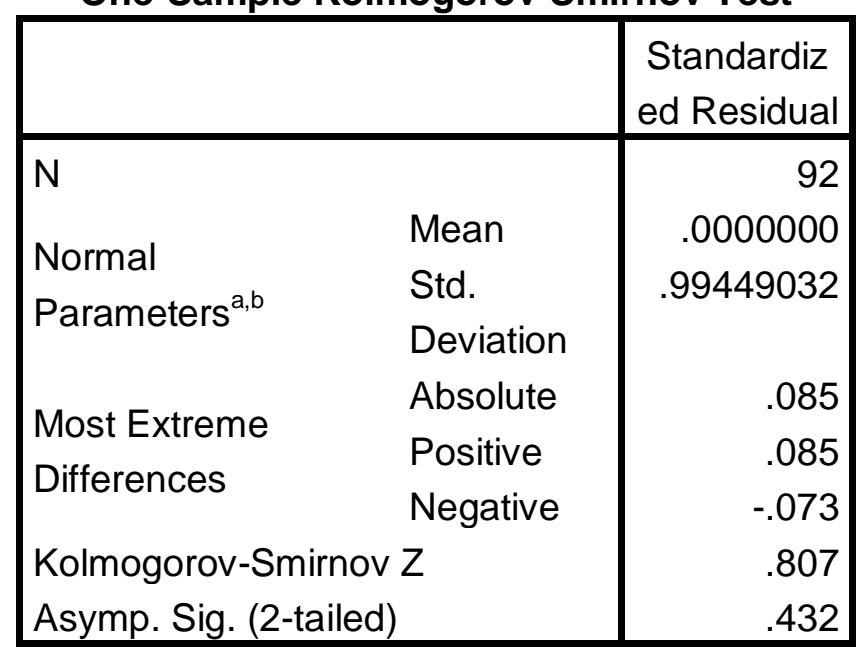

a. Test distribution is Normal.

b. Calculated from data.

Dari tabel di atas, dapat dilihat bahwa nilai Asymp. Sig (2 tailed) memiliki nilai sebesar 0.432. nilai signifikansi ini lebih besar dari 0.05, sehingga dapat disimpulkan seluruh data dalam penelitian ini telah terdistribusi secara normal. 


\section{Uji Heteroskedastisitas} berikut ini:

Uji heteroskedastisitas dalam penelitian ini dapat dilihat pada gambar scatter plot

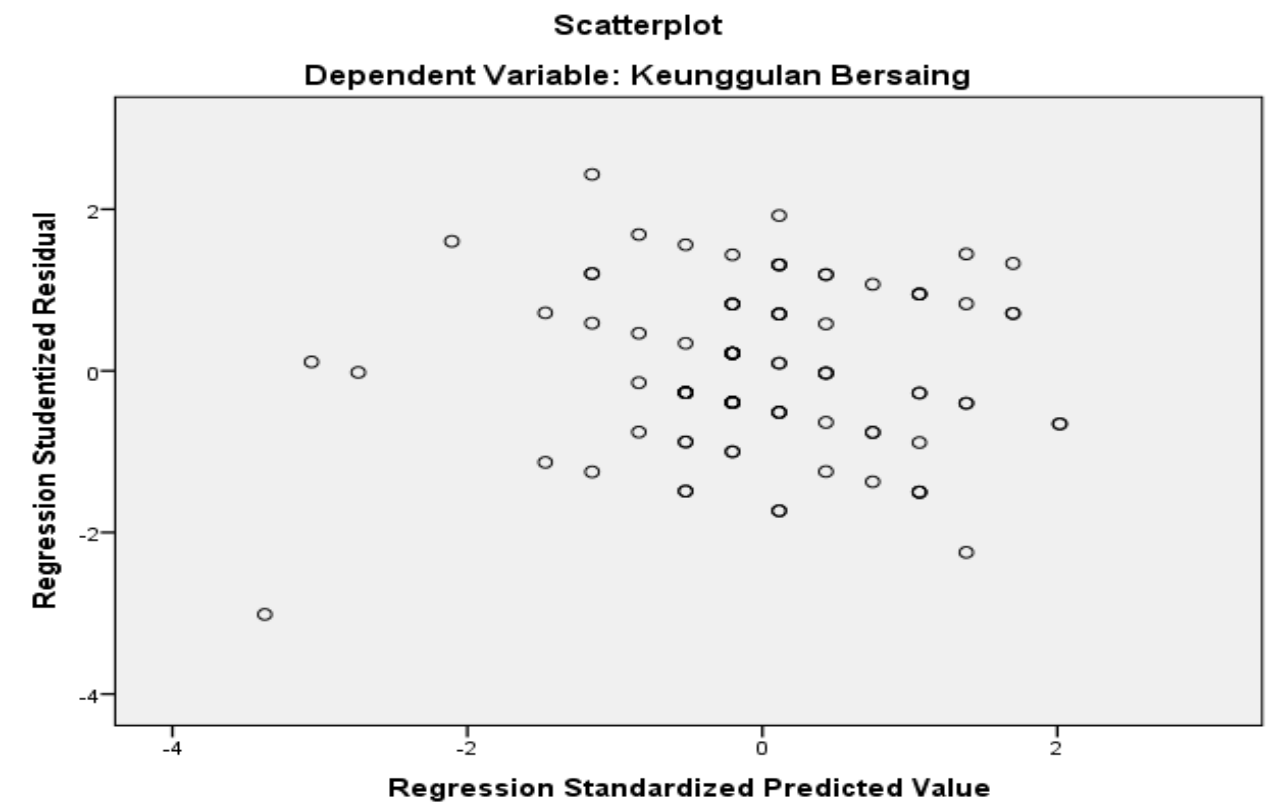

Gambar 1. Scatter Plot

Dari gambar di atas, dapat dilihat bahwa titik-titik telah menyebar di atas dan di bawah angka nol (0) pada sumbu Y, dan sebaran titik-titik tersebut tidak membentuk pola yang jelas, sehingga dapat disimpulkan bahwa data dalam penelitian ini tidak terjadi masalah heteroskedastisitas.

\section{Analisis Koefisien Determinasi}

Analisis koefisien determinasi dapat dilihat pada tabel berikut:

Tabel 5. Analisis Koefisien Determinasi

Model Summary ${ }^{b}$

\begin{tabular}{|l|r|r|r|r|}
\hline Model & R & R Square & Adjusted R Square & $\begin{array}{c}\text { Std. Error of the } \\
\text { Estimate }\end{array}$ \\
\hline 1 & $.451^{\mathrm{a}}$ & .240 & .187 & 1.851 \\
\hline
\end{tabular}

a. Predictors: (Constant), Harga

b. Dependent Variable: Loyalitas Pelanggan

Dari tabel di atas, dapat dilihat bahwa nilai $\mathrm{R}$ sebesar 0.451 atau sebesar $45.1 \%$. Hal ini menunjukkan bahwa harga mampu menjelaskan loyalitas pelanggan sebesar $45.1 \%$, sedangkan sisanya sebesar $54.9 \%$ dipengaruhi oleh variabel lain yang tidak dimasukkan dalam penelitian ini 


\section{Uji Hipotesis}

Uji Parsial (Uji t)

Hasil pengujian hipotesis pada penelitian dapat dilihat pada tabel berikut:

Tabel 6. Uji Parsial (Uji t)

Coefficients $^{\mathrm{a}}$

\begin{tabular}{|c|c|c|c|c|c|c|}
\hline \multirow{2}{*}{\multicolumn{2}{|c|}{ Model }} & \multicolumn{2}{|c|}{$\begin{array}{c}\text { Unstandardized } \\
\text { Coefficients }\end{array}$} & \multirow{2}{*}{$\begin{array}{c}\text { Standardized } \\
\text { Coefficients } \\
\text { Beta } \\
\end{array}$} & \multirow[t]{2}{*}{$\mathrm{T}$} & \multirow[t]{2}{*}{ Sig. } \\
\hline & & $\mathrm{B}$ & Std. Error & & & \\
\hline \multirow{2}{*}{1} & (Constant) & 7.014 & 1.030 & & 7.724 & .000 \\
\hline & Harga & .301 & .073 & .361 & 3.673 & .000 \\
\hline
\end{tabular}

a. Dependent Variable: Loyalitas Pelanggan

Berdasarkan tabel di atas, dapat dilihat bahwa nilai signifikansi variabel harga sebesar 0.000. Nilai signifikansi ini lebih kecil dari 0.05. sehingga dapat disimpulkan bahwa harga berpengaruh signifikan terhadap loyalitas pelanggan. Maka hipotesis yang diajukan dalam penelitian ini diterima.

\section{Pembahasan}

1. Harga berpengaruh signifikan terhadap Loyalitas Pelanggan

Harga dalam penelitian ini berpengaruh signifikan terhadap loyalitas pelanggan. Hal ini dikarenakan oleh karakteristik dari konsumen adalah memperoleh produk dengan kualitas yang baik dengan harga yang bersaing. Dikarenakan banyak perusahaan yang menghasilkan atau menjual produk yang sejenis dengan yang dihasilkan oleh PT Golden Batam Raya, maka tidak sulit bagi pelanggan untuk mendapatkan produk yang berkualitas dengan harga yang bersaing.

\section{SIMPULAN}

Berdasarkan hasil penelitian, maka dapat diambil kesimpulan sebagai berikut:

1. Harga memberikan pengaruh yang signifikan terhadap loyalitas pelanggan

2. Harga memberikan pengaruh sebesar $45.1 \%$ terhadap loyalitas pelanggan. Maka perusahaan harus dapat dengan tepat menetapkan harga jual produk

\section{DAFTAR PUSTAKA}

Hasan, Ali (2014). Marketing dan Kasus-Kasus Pilihan. Cetakan Kedua, Yogyakarta. CAPS (Center for Academic Publishing Service)

Kotler, Philip dan Kevin Lane Keller (2009). Manajemen Pemasaran Jilid 1. Edisi Keduabelas. Indeks, Jakarta

Sangadji, Etta, dan Sopiah (2013). Perilaku Konsumen Yogyakarta: CV. Andi Offset 